\title{
A Study on Relationship between Job Satisfaction and Organizational Role Stress of Women Extension Personnel
}

\author{
C.N. Anshida Beevi ${ }^{1 *}$, Monika Wason ${ }^{2}$, R.N. Padaria ${ }^{2}$, Premlata Singh ${ }^{2}$, \\ Niveta Jain $^{3}$ and Eldho Varghese ${ }^{4}$ \\ ${ }^{1}$ ICAR-CRIDA, Hyderabad, India \\ ${ }^{2}$ Division of Agricultural Extension, India \\ ${ }^{3}$ CESCRA, ICAR-IARI, India \\ ${ }^{4}$ ICAR-CMFRI, Cochin, India \\ *Corresponding author
}

\begin{abstract}
A B S T R A C T
Job satisfaction and organizational stress of the extension personnel are very crucial for improving their performance and thereby achieving organizational effectiveness. Thus the need of the hour in human resource management are reducing organizational stress and

\section{Keywords}

Job satisfaction; Organizational role stress, Extension personnel

\section{Article Info}

Accepted: 17 July 2018 Available Online: 10 August 2018 increasing job satisfaction of the extension personnel with a view of improving their efficiency through motivation. Hence, the present study has made an attempt to understand the relationship between job satisfaction and organizational stress of women extension personnel which is highly important in the context of increasing feminization of agriculture. For the present study, the research design adopted was Ex-post-facto. Multistage random sampling technique was adopted for the study. A total of 210 women extension personnel were selected as sample for the study including sixty women agricultural officers, 120 women agricultural assistants and 30 VFPCK women extension personnel. To measure the job satisfaction a Likert-type scale was developed following summated rating method. Organizational role stress was measured using a Likert-type scale developed by Udai Pareek. Self-report measures were used to obtain the data. Spearman's bivariate correlation for job satisfaction and organizational role stress for different groups of women extension personnel from State Department and VFPCK showed that there was a statistically significant relation between these two variables at 1 per cent level of probability. There was a strong and negative correlation between job satisfaction and organizational role stress of women extension personnel.
\end{abstract}

\section{Introduction}

One of the main concerns in human resource development in agricultural extension organization is improving the performance of extension personnel. Job satisfaction and organizational stress of the extension personnel are very crucial for improving their performance and thereby achieving organizational effectiveness. Thus the need of the hour in human resource management are reducing organizational stress and increasing job satisfaction of the extension personnel with a view of improving their efficiency 
through motivation. Hence, organizational stress and job satisfaction are receiving increasing attention in the academic literature and has become a salient issue for the extension organizations.

Job satisfaction of the employees in an organization is an important indicator of the health of that organization. Locke (1976) defined job satisfaction as a pleasurable positive state resulting from one's job and job experience. Individuals show pleasurable positive attitudes when they are satisfied with their job. Singh (1989) opined that the job satisfaction is a part of life satisfaction, which reflects the nature of one's job environment. Several researches has been conducted on this line and shown that satisfied employees are more likely to stay in the organization than those who are dissatisfied (Mobley, Griffeth, Hand and Megliano, 1979). There are a variety of factors that can influence a person's level of job satisfaction like pay, promotion system, working conditions, leadership, social relationship and the job-itself. Job satisfaction is basically an individual matter and refers to what one expects from his or her job and when there is mismatch between what is expected and what is received and if there is some disparity, then dissatisfaction occurs. The study conducted by Faizuniah et al., (2011) showed that low levels of reward and responsibility leads to low level of job satisfaction. Some of the organizational factors that affect individual job satisfaction include organizational culture (Lee and Chang, 2008; Singh and Singh, 2009), job characteristics (Galup et al., 2008) and job security (Noble, 2008). Some of the individual factors are the level of job stress (Singh and Singh, 2009), job experience (Kumar and Giri, 2009) and employee work orientation (Donovan et al., 2004).

The term "stress" was first used by Selye (1936) in the literature on life sciences, describing stress as the force, pressure or strain exerted upon a material object or person which resist these forces and attempt to maintain its original state. Occupational stress is defined as a condition arising from the interaction of people and their jobs and characterized by changes within people that force them to deviate from their normal functioning (Beehr and Newman, 1978). Different studies have classified occupational stress in terms of physical environment, role stressors, organizational structure, job characteristics, professional relationships, career development and work-versus-family conflict (Burke, 1993). Stress in the work place is increasingly a critical problem for employees, employers and the society. According to Spilberger (1980) stress is not always dysfunctional in nature, and if stress is positive, it can prove as one of the most important factors in improving productivity within an organization. There are many variables which have been related to organizational stress.

Several studies have tried to determine the link between stress and job satisfaction. Job satisfaction and organizational stress are the two key focuses in human resource management researchers and concluded that stress and satisfaction are inversely related (Hollon and Chesser, 1976; Miles and Petty, 1975). Fletcher and Payne (1980) identified that a lack of satisfaction can be a source of stress, while high satisfaction can alleviate the effects of stress. This study reveals that, both of job stress and job satisfaction were found to be interrelated. Nowadays, stress and burnout have become two of the buzzwords of the present century influencing job satisfaction of the employees (Banet et al., 2005; Verma, 2008). Hence, the present study has made an attempt to understand the relationship between job satisfaction and organizational stress of women extension personnel which is highly important in the context of increasing feminization of agriculture. 


\section{Materials and Methods}

For the present study, the research design adopted was Ex-post-facto. Multistage random sampling technique was adopted for the study. During first stage, districts were selected and in second stage, respondents were selected. Sixty women agricultural officers, 120 women agricultural assistants and 30 VFPCK women extension personnel represented the whole sample. Hence, a total of 210 women extension personnel were selected as sample for the study. To measure the job satisfaction a Likert-type scale was developed following summated rating method.

The scale developed was pre-tested during pilot study and Cronbach's alpha found to be 0.86. Organizational role stress was measured using a Likert-type scale developed by Udai Pareek. Scale consisted of two broad groups of stresses namely family role stressor and work role stressors.

The scale was pre-tested during pilot study and Cronbach's alpha found to be 0.95 which is significant. The data were collected through administering questionnaire from respondents during office hours. Self-report measures were used to obtain the data. Data were analyzed using suitable statistical tools.

\section{Results and Discussion}

Studies on job satisfaction and organizational role stress imply that both are interrelated. Job satisfaction can be an important indicator of how employees feel about their jobs and predictor of work behaviour (Wegge, Schmidt, Parks and Dick, 2007; Saari and Judge, 2004 and Verma, 2008).

Considering this, an analysis was done to find out the relationship between them. For that two hypotheses were formulated.

\section{Hypotheses}

Null Hypothesis, H0: There is no relationship between job satisfaction and organizational role stress of women extension personnel

Alternate Hypothesis, H1: There is a negative relation between job satisfaction and organizational role stress of women extension personnel

To study the relation between job satisfaction and organizational role stress, correlation between these two were calculated. Since both the variables were measured at ordinal level Spearman's rank order correlation was worked out using SPSS.

Spearman's bivariate correlation for job satisfaction and organizational role stress for different groups of women extension personnel from State Department and VFPCK showed that there was a statistically significant relationship between these two variables at 1per cent level of significance.

Hence, the null hypothesis was rejected. Results shown in Table 1 indicates that job satisfaction and organizational role stress were strongly and negatively correlated, with $\mathrm{r}$ (58) $=-0.77$ for women agricultural officers, $r$ $(118)=-0.80$ for women agricultural assistants and $\mathrm{r}(28)=-0.92$ for VFPCK women extension personnel, $\mathrm{p}<0.01$. There is a strong and negative correlation between job satisfaction and organizational role stress of women extension personnel and the alternate hypothesis accepted at 1per cent level of significance.

The results are in line with the previous studies. Cummins (1990) suggested that job stressors are predictive of job dissatisfaction. One of the important factors affecting individual job satisfaction is the level of job stress (Singh and Singh, 2009). 
Table.1 Spearman's rank correlation between job satisfaction and organizational role stress among different groups $(\mathrm{N}=210)$

\begin{tabular}{|l|l|l|l|}
\hline Sl. No. & \multicolumn{1}{|c|}{ Category } & df & \multicolumn{1}{|c|}{ Co-efficient } \\
\hline 1. & Women Agricultural Officers $\left(\mathrm{n}_{1}=60\right)$ & 58 & $-0.77^{* *}$ \\
\hline 2. & Women Agricultural Assistants $\left(\mathrm{n}_{2}=120\right)$ & 118 & $-0.80^{* *}$ \\
\hline 3. & VFPCK Women Extension Personnel $\left(\mathrm{n}_{3}=30\right)$ & 28 & $-0.92^{* *}$ \\
\hline
\end{tabular}

Correlations marked with two asterisks $\left({ }^{* *}\right)$ were significant at $1 \%$ level of significance

Table.2 Cluster distribution of women extension personnel

\begin{tabular}{|c|c|c|c|c|c|c|}
\multicolumn{3}{|c|}{ Cluster Distribution } & \multicolumn{4}{c|}{ Cluster centroids } \\
\hline Cluster & N & Percentage of Combined & Organizational Role Stress & Job Satisfaction \\
\hline 1 & 73 & $34.80 \%$ & 33.37 & 8.99 & 84.89 & 6.24 \\
\hline 2 & 137 & $65.20 \%$ & 79.79 & 16.23 & 69.01 & 4.63 \\
\hline Total & 210 & $100.0 \%$ & 63.65 & 26.27 & 74.53 & 9.21 \\
\hline
\end{tabular}

Cluster analysis based on job satisfaction and organizational role stress

Based on the score obtained for job satisfaction and organizational role stress a cluster analysis was done for whole sample. Two-step cluster analysis was used for clustering the sample. Results of two-step cluster analysis (Table 2) for whole sample in SPSS formed two clusters. First cluster formed with 73 women extension personnel $(34.80 \%)$ and the second one with 137 $(65.20 \%)$ women extension personnel.

It is clear from the above table that the job satisfaction of extension personnel in first cluster was comparatively more than that of second one. But in the case of organizational role stress it was vice versa. Hence, the first cluster was named as satisfied extension personnel and the other one as stressed extension personnel.

Stressful work fosters decisions to leave the employer (Firth, Mellor, Moore and Loquet, 2004), increases absenteeism and affects employee productivity (Jex, 1998). In the present study, Spearman's bivariate correlation for job satisfaction and organizational role stress for different groups of women extension personnel from State Department and VFPCK showed that there was a statistically significant relation between these two variables at 1 per cent level of probability.

There was a strong and negative correlation between job satisfaction and organizational role stress of women extension personnel. Strong negative correlation implies that high levels of work stress are associated with low levels of job satisfaction (Landsbergis, 1988; Terry et al., 1993).

Similarly, Moore et al., (1984) found in a study that role conflict and role ambiguities were significant predictors of job satisfaction. In addition, sex, years of tenure, changes in program responsibilities and number of professionals interacted on a regular basis, number of support staff worked with on a regular basis, responsibility for supervision and training received on youth issues were also significant predictors of job satisfaction. 


\section{Acknowledgement}

Authors are thankful to the respondents, for their support during the data collection. First author is thankful to the Indian Council of Agricultural Research (ICAR), Government of India for providing the financial assistance in the form of SRF to carry out the research.

\section{References}

Banet, Plint and Clifford. (2005). Reducing stress and avoiding burnout: A collection of activities for prescholars. 11(2): 28-32.

Beehr, T. A. and Newman, J. E. (1978). Job stress, employee health, and organizational effectiveness: A facet analysis model and literature review. Personnel Psychology, 31(4): 665-699.

Burke, R. J. (1993). Toward an understanding of psychological burnout among police officers. Journal of Social Behavior and Personality, 8(3): 425-438.

Cummins, R. C. (1990). Job stress and the buffering effect of supervisory support. Group and Organization Studies, 15(1): 92-104.

Donovan, D. T., Brown, T. J. and Mowen, J. C. (2004). Internal benefits of serviceworker customer orientation: Job satisfaction, commitment and organizational citizenship behaviour. Journal of Marketing, 68: 128-146.

Faizuniah, P., Khulida, K. Y., Johanim, J., Mohammed Faizal, M. I. and Zulkiflee, D. (2011). The relationship between organizational climate and job satisfaction: The case of a government agency in Malaysia. International Journal of Humanities and Social Science, 1(12): 152-160.

Firth, L., Mellor, D. J., Moore, K. A. and Loquet, C. (2004). How can managers reduce employee intention to quit? Journal of managerial psychology, 19(2): 170-187.

Fletcher, B. and Payne, R. L. (1980). Stress and work: A review and theoretical framework. Personnel Review, 9(1): 1929.

Galup, S. D., Klein, G. and Jiang, J. J. (2008). The impacts of job characteristics on IS employee satisfaction: A comparison between permanent and temporary employees. Journal of Computer Information Systems, 58-68.

Hollon, C. J. and Chesser, R. J. (1976). The relationship of personal influence dissonance to job tension, satisfaction and involvement. Academy of Management Journal, 19: 308-314.

Jex, S. M. (1998). Stress and job performance: Theory, research, and implications for managerial practice. Sage Publications Ltd.

Kumar, B. P. and Giri, V. N. (2009). Effect of age and experience on job satisfaction and organizational commitment. The ICFAI Journal of Organizational Behaviour, 8(1): 28-36.

Landsbergis, P. A. (1988). Occupational stress among health care workers: a test of the job demands- control model. Journal of Organizational Behavior, 9(3): 217-239.

Lee, Y. D. and Chang, H. M. (2008). Relations between team work and innovation in organization and the job satisfaction of employees: A factor analytic study. International Journal of Management, 25(3): 732-739.

Locke, E. A. (1976). The nature and causes of job satisfaction. In M.D. Dunnette (Ed.), Handbook of industrial and organizational psychology, 1297-1349. Chicago: Rand McNally.

Miles, R. H. and Petty, M. M. (1975). Relationship between role clarity, need for clarity, and job-tension and satisfaction for supervisory and non- 
supervisory roles. Academy of Management Journal, 18: 877-883.

Mobley, W., Griffeth, R., Hand, H. and Megliano, B. (1979). Review and conceptual analysis of the employee turnover process. Psychological bulletin, 86: 493-522.

Moore, J. and Robert. (1984). The effect of role conflict and role ambiguity on the use of pioneer, job-satisfaction and casual attributions, Dissertation Abstracts International, 42: 233.

Noble, C. H. (2008). The influence of job security on field sales manager satisfaction: Exploring frontline tensions. Journal of Personal Selling and Sales Management, 28: 247-261.

Pareek, U. and Purohit, S. (2010). Training Insruments in HRD and OD, Third edition, McGraw Hill Education (India) Private Limited, New Delhi.

Saari, L. M. and Judge, T. A. (2004). Employee attitudes and job satisfaction. Human resource management, 43(4): 395-407.

Selye, H. (1936). A syndrome produced by diverse noxious agents. Nature, 138: 32-35.

Singh, A. P. and Singh, S. (2009). Effects of stress and work culture on job satisfaction. The ICFAI Journal of Organizational Behaviour, 8(2): 52-62.

Singh, P. (1989). Women scientists of ICAR - A Multidimensional Study. PhD Thesis, Division of Agricultural Extension, Indian Agricultural Research Institute, New Delhi, India.

Spielberger, C. (1980). Preliminary manual for the state-trait anger scale. Tampa, FL: University of South Florida.

Terry, D. J., Nielsen, M. and Perchard, L. (1993). Effects of work stress on psychological wellbeing and job satisfaction: the stress-buffering role of social support, Australian Journal of Psychology, 45 (3): 168-75.

Verma, S. (2008). Stress Questionnaire for Lawyers: Implications of Burnout and Psychosocial Stressors for the job satisfaction among male and female lawyers, Unpublished M.Phil Thesis, Himachal Pradesh University, Shimla, (India).

Wegge, J., Schimedit, K. Parker, E. and Van Dick, K. (2007). Taking a sickic: job satisfaction and job-involvement as interactive predictor of absenteeism in a public organization. Journal of Occupational and Organizational Psychology, 80: 77-89.

\section{How to cite this article:}

Anshida Beevi, C.N., Monika Wason, R.N. Padaria, Premlata Singh, Niveta Jain and Eldho Varghese. 2018. A Study on Relationship between Job Satisfaction and Organizational Role Stress of Women Extension Personnel. Int.J.Curr.Microbiol.App.Sci. 7(08): 2877-2882. doi: https://doi.org/10.20546/ijcmas.2018.708.304 